\title{
Time course study of oxidative and nitrosative stress and antioxidant enzymes in $\mathbf{K}_{2} \mathbf{C r}_{2} \mathbf{O}_{7}$-induced nephrotoxicity
} José Pedraza-Chaverrí*1, Diana Barrera ${ }^{2}$, Omar N Medina-Campos ${ }^{1}$, Raymundo C Carvajal ${ }^{1}$, Rogelio Hernández-Pando ${ }^{3}$, Norma A MacíasRuvalcaba ${ }^{4}$, Perla D Maldonado ${ }^{1}$, Marcos I Salcedo ${ }^{1}$, Edilia Tapia ${ }^{5}$, Liliana Saldívar ${ }^{6}$, María E Castilla ${ }^{6}$ and María E Ibarra-Rubio ${ }^{1}$

\begin{abstract}
Address: ${ }^{1}$ Facultad de Química, Departamento de Biología, Edificio B, Segundo Piso, Laboratorio 209, Universidad Nacional Autónoma de México (UNAM), Ciudad Universitaria, 04510, México, D.F., México, ²Facultad de Medicina, Departamento de Farmacología, Universidad Nacional Autónoma de México (UNAM), Ciudad Universitaria, 04510, México, D.F., México, ${ }^{3}$ Instituto Nacional de Ciencias Médicas y Nutrición "Salvador Zubirán", Departamento de Patología, 14000, México, D.F., México, ${ }^{4}$ Facultad de Química, Edificio B, Laboratorio 124, Departamento de Química Orgánica, Universidad Nacional Autónoma de México (UNAM), Ciudad Universitaria 04510, México, D.F., México, ${ }^{5}$ Departamento de Nefrología, Instituto Nacional de Cardiología "Ignacio Chávez", Juan Badiano \#1, Col Sección XVI, 14080 Tlalpan, México, D.F., México and 'Facultad de Química, Edificio B, Departamento de Química Analítica, Universidad Nacional Autónoma de México (UNAM), Ciudad Universitaria 04510, México, D.F., México

Email: José Pedraza-Chaverrí* - pedraza@servidor.unam.mx; Diana Barrera - dianabarrera@hotmail.com; Omar N MedinaCampos - mconoel@servidor.unam.mx; Raymundo C Carvajal - clementecarbajal@hotmail.com; Rogelio HernándezPando - rhdezpando@ hotmail.com; Norma A Macías-Ruvalcaba - normaamr@hotmail.com; Perla D Maldonado - m_cdeyanira@yahoo.com; Marcos I Salcedo - ni_be_pb@hotmail.com; Edilia Tapia - ediliatapia@hotmail.com; Liliana Saldívar - saldivar@servidor.unam.mx; María E Castilla - elenacm@servidor.unam.mx; María E Ibarra-Rubio - meir@servidor.unam.mx

* Corresponding author
\end{abstract}

Published: 26 April 2005

BMC Nephrology 2005, 6:4 doi:10.1 |86//47|-2369-6-4

This article is available from: http://www.biomedcentral.com/I47I-2369/6/4

(c) 2005 Pedraza-Chaverrí et al; licensee BioMed Central Ltd.

This is an Open Access article distributed under the terms of the Creative Commons Attribution License (http://creativecommons.org/licenses/by/2.0), which permits unrestricted use, distribution, and reproduction in any medium, provided the original work is properly cited.
Received: 30 October 2004

Accepted: 26 April 2005

\begin{abstract}
Background: Potassium dichromate $\left(\mathrm{K}_{2} \mathrm{Cr}_{2} \mathrm{O}_{7}\right)$-induced nephrotoxicity is associated with oxidative and nitrosative stress. In this study we investigated the relation between the time course of the oxidative and nitrosative stress with kidney damage and alterations in the following antioxidant enzymes: $\mathrm{Cu}, \mathrm{Zn}$ superoxide dismutase (Cu, Zn-SOD), Mn-SOD, glutathione peroxidase (GPx), glutathione reductase (GR), and catalase (CAT).

Methods: Nephrotoxicity was induced in rats by a single injection of $\mathrm{K}_{2} \mathrm{Cr}_{2} \mathrm{O}_{7}$. Groups of animals were sacrificed on days I,2,3,4,6,8,I0, and I2. Nephrotoxicity was evaluated by histological studies and by measuring creatinine clearance, serum creatinine, blood urea nitrogen (BUN), and urinary excretion of $\mathrm{N}$-acetyl- $\beta$-D-glucosaminidase (NAG) and total protein. Oxidative and nitrosative stress were measured by immunohistochemical localization of protein carbonyls and 3nitrotyrosine, respectively. $\mathrm{Cu}, \mathrm{Zn}-\mathrm{SOD}, \mathrm{Mn}-\mathrm{SOD}$, and CAT were studied by immunohistochemical localization. The activity of total SOD, CAT, GPx, and GR was also measured as well as serum and kidney content of chromium and urinary excretion of $\mathrm{NO}_{2}-/ \mathrm{NO}_{3}-$. Data were compared by two-way analysis of variance followed by a post hoc test.

Results: Serum and kidney chromium content increased reaching the highest value on day $\mathrm{I}$. Nephrotoxicity was made evident by the decrease in creatinine clearance (days I-4) and by the increase in serum creatinine (days I-4), BUN (days I-6), urinary excretion of NAG (days I-4), and
\end{abstract}


total protein (day I-6) and by the structural damage to the proximal tubules (days I-6). Oxidative and nitrosative stress were clearly evident on days I-8. Urinary excretion of $\mathrm{NO}_{2}-/ \mathrm{NO}_{3}$ - decreased on days 2-6. Mn-SOD and $\mathrm{Cu}, \mathrm{Zn}-\mathrm{SOD}$, estimated by immunohistochemistry, and total SOD activity remained unchanged. Activity of GPx decreased on days 3-I2 and those of GR and CAT on days $2-10$. Similar findings were observed by immunohistochemistry of CAT.

Conclusion: These data show the association between oxidative and nitrosative stress with functional and structural renal damage induced by $\mathrm{K}_{2} \mathrm{Cr}_{2} \mathrm{O}_{7}$. Renal antioxidant enzymes were regulated differentially and were not closely associated with oxidative or nitrosative stress or with kidney damage. In addition, the decrease in the urinary excretion of $\mathrm{NO}_{2}{ }^{-} / \mathrm{NO}_{3}{ }^{-}$was associated with the renal nitrosative stress suggesting that nitric oxide was derived to the formation of reactive nitrogen species involved in protein nitration.

\section{Background}

$\mathrm{K}_{2} \mathrm{Cr}_{2} \mathrm{O}_{7}$ is a chemical compound that is widely used in metallurgy, chrome plating, chemical industry, textile manufacture, wood preservation, photography and photoengraving, refractory and stainless steel industry, and cooling systems [1]. Occupational exposure to chromium has been associated with welders, chrome-plating workers, and chromium pigment factories workers [2]. Chromium is known to cause allergic dermatitis [3], carcinogenicity [4], and ARF in humans $[2,5,6]$ and in animals [7-11].

Acute renal failure (ARF) induced by potassium dichromate $\left(\mathrm{K}_{2} \mathrm{Cr}_{2} \mathrm{O}_{7}\right)$ has been used as a model to study the pathophysiology of this disease [7,9]. Experimental data show that chromate affects selectively the convoluted section of the proximal tubules [7,12-15] and induces acute necrosis of renal tubules $[14,15]$. Clinical and experimental renal damage induced by $\mathrm{K}_{2} \mathrm{Cr}_{2} \mathrm{O}_{7}$ has been associated with oxidative stress [15-20]. In fact, some antioxidants such as ascorbic acid, vitamin E, N-acetyl cysteine, and glutathione prevent the $\mathrm{K}_{2} \mathrm{Cr}_{2} \mathrm{O}_{7}$ induced renal damage [21-25] whereas the inhibition of glutathione biosynthesis enhances it $[22,24]$. Evidences suggest that reactive oxygen species (ROS) are involved in $\mathrm{Cr}(\mathrm{VI})$-induced cell injury $[16,17,19,26]$. Chromium reduction intermediates $[\mathrm{Cr}(\mathrm{V}), \mathrm{Cr}(\mathrm{IV})$, and $\mathrm{Cr}(\mathrm{III})]$, which could be generated under physiological conditions, may be toxic as they involve ROS production [27-29]. In vitro chromate reduction via $\mathrm{H}_{2} \mathrm{O}_{2}$ has been shown to produce hydroxyl radicals via a Fenton-like reaction [27,30-33].

We recently showed that stannous chloride $\left(\mathrm{SnCl}_{2}\right)$ pretreatment has a protective role in $\mathrm{K}_{2} \mathrm{Cr}_{2} \mathrm{O}_{7}$-induced nephrotoxicity $[15,34] . \mathrm{SnCl}_{2}$ is a potent inductor of heme oxygenase-1 $[15,35]$ and the protective role of $\mathrm{SnCl}_{2}$ in this experimental model has been attributed, at least in part, to the heme oxygenase-1 preinduction [15,34]. We also showed that renal activity of $\mathrm{Cu}, \mathrm{Zn}-\mathrm{SOD}, \mathrm{Mn}-\mathrm{SOD}$, and GR remained unchanged at 24 and $48 \mathrm{~h}$ whereas GPx and CAT activities remained unchanged at $24 \mathrm{~h}$ but decreased at $48 \mathrm{~h}$ in $\mathrm{K}_{2} \mathrm{Cr}_{2} \mathrm{O}_{7}$-injected rats. In the present work we performed a time course study of functional and structural renal damage, oxidative and nitrosative stress, and the behavior of the antioxidant enzymes $\mathrm{Cu}, \mathrm{Zn}$ superoxide dismutase ( $\mathrm{Cu}, \mathrm{Zn}-\mathrm{SOD}), \mathrm{Mn}$ superoxide dismutase (Mn-SOD), glutathione reductase (GR), glutathione peroxidase (GPx), and catalase (CAT) in $\mathrm{K}_{2} \mathrm{Cr}_{2} \mathrm{O}_{7^{-}}$ induced nephrotoxicity to know if the antioxidant enzymes respond in a coordinate way and if there is an association between (a) oxidative/nitrosative stress and renal damage, (b) oxidative/nitrosative stress and the antioxidant enzymes, and (c) antioxidant enzymes and renal damage.

\section{Methods \\ Reagents}

Formaldehyde, anhydrous absolute ethanol, xylol, methanol, chloroform, and $\mathrm{K}_{2} \mathrm{Cr}_{2} \mathrm{O}_{7}$ were from J.T. Baker (México, D.F.), p-nitrophenyl-N-acetyl- $\beta$-D-glucosaminide, acrylamide, NADPH, N, N'-methylene-bis-acrylamide, xanthine, xanthine oxidase, nitroblue tetrazolium (NBT), $\beta$-nicotinamide adenine dinucleotide phosphate, reduced form $(\beta-\mathrm{NADPH})$, aprotinin, leupeptin, pepstatin, and 2,4-dinitrophenylhydrazine (DNPH) were from Sigma Chemical Co. (St. Louis, MO, USA). Commercial kits to measure creatinine and blood urea nitrogen were from Spinreact (Girona, Spain). Rabbit anti-rat polyclonal antibodies against Mn-SOD (Cat. \# SOD 111) and Cu, ZnSOD (Cat. \# SOD 101) were from Stressgen Biotechnologies Co. (Victoria, BC, Canada). Rabbit anti-human CAT polyclonal antibodies (Cat. \# 219010) were from Calbiochem (San Diego, CA, USA). Goat anti-dinitrophenol (DNP) polyclonal antibodies (Cat. \# J06) were from Biomeda Corporation (Foster City, CA, USA). Rabbit anti3-nitrotyrosine (3-NT) polyclonal antibodies (Cat. \#06284) were from Upstate (Lake Placid, NY, USA). Anti-rabbit immunoglobulin horseradish peroxidase antibodies (Cat. \# NA-934) were from Amersham (Buckinghamshire, UK). Donkey anti-goat horseradish peroxidase antibodies (Cat. \# SC2020) were from Santa Cruz Biotechnology, Inc. (Santa Cruz, CA, USA). Enhanced chemiluminiscence 
(ECL) kit for Western blot was purchased from Amersham Life Sciences (Buckinghamshire, England). All other chemicals were reagent grade and commercially available.

\section{Experimental design}

Seven-week-old male Wistar rats with an initial body weight of 200-210 g were used. Experimental work was approved by CONACYT (\#25441) and DGAPA (IN210201) and followed the guidelines of Norma Oficial Mexicana (NOM-ECOL-087-1995). Two groups of rats were studied: 1) CT, control injected subcutaneously with $0.5 \mathrm{ml}$ isotonic saline solution $(\mathrm{n}=40)$; and 2$)$ $\mathrm{K}_{2} \mathrm{Cr}_{2} \mathrm{O}_{7}$, treated with a single subcutaneous injection of $15 \mathrm{mg} / \mathrm{Kg} \mathrm{K}_{2} \mathrm{Cr}_{2} \mathrm{O}_{7}$ [7] in a volume of $0.5 \mathrm{ml}(\mathrm{n}=43)$. The study was performed in two stages: rats from days $1,2,3,4$, and 6 were studied in the first one ( $\mathrm{n}=5 /$ per group) and rats from days 8,10 , and 12 were studied in the second one ( $\mathrm{n}=5$ for control group and $\mathrm{n}=6$ for $\mathrm{K}_{2} \mathrm{Cr}_{2} \mathrm{O}_{7}$ group). Rats were sacrificed on days $1,2,3,4,6,8,10$, and 12 . There was no mortality. Rats had free access to water and CT group was pair-fed to match the food intake of $\mathrm{K}_{2} \mathrm{Cr}_{2} \mathrm{O}_{7}$ group. Animals were maintained in metabolic cages to collect 24 -h urine to measure $\mathrm{N}$-acetyl- $\beta$ - $\mathrm{D}$-glucosaminidase (NAG), total protein, creatinine, and $\mathrm{NO}_{2}{ }^{-} / \mathrm{NO}_{3}{ }^{-}$.

Animals were sacrificed by decapitation and trunk blood was collected at room temperature to obtain serum to measure chromium content and the markers of renal function, creatinine and blood urea nitrogen (BUN). Glomerular filtration rate was estimated by creatinine clearance. The kidneys were obtained to perform histological analysis, chromium determination, the activity of antioxidant enzymes, Western blot of CAT, Cu, Zn-SOD, and $\mathrm{Mn}-\mathrm{SOD}$, and the immunohistochemical localization of 3-NT, protein carbonyls, CAT, Cu, Zn-SOD, and MnSOD.

\section{Chromium concentration}

Chromium content in serum and in total kidney was measured by graphite-furnace atomic-absorption spectrometry on a Perkin Elmer 3110 device with furnace.

\section{Markers of nephrotoxicity}

Creatinine and BUN were measured using commercial kits according to the instructions of manufacturers and were expressed as $\mathrm{mg} / \mathrm{dL}$. Creatinine clearance was calculated with the serum and urine data according to the standard formula. Urinary NAG excretion was determined at $405 \mathrm{~nm}$ using p-nitrophenyl- $\mathrm{N}$-acetyl- $\beta$-D-glucosaminide as substrate and the data were expressed as $\mathrm{U} / 24 \mathrm{~h}$ $[7,15]$. One unit of NAG was defined as the amount of enzyme that releases $1 \mu \mathrm{mol}$ of p-nitrophenol in the assay conditions. Total protein in urine was measured by a turbidimetric method with $12.5 \%$ trichloroacetic acid at 420 $\mathrm{nm}[7,15]$ and the data were expressed as $\mathrm{mg} / 24 \mathrm{~h}$.

\section{Histological studies}

Thin slices of kidney tissue with cortex and medulla were fixed by immersion in buffered formalin ( $\mathrm{pH} 7.4$ ), dehydrated and embedded in paraffin. Sections $(4 \mu \mathrm{m})$ were stained with hematoxylin and eosin (H\&E) [15]. A quantitative histological damage was determined by using a Leica Qwin Image Analyzer (Cambridge, UK). The histological profile of twenty proximal tubules randomly selected per rat ( 5 rats per group) was recorded ( $n=100$ tubuli/group at each time point). The number of tubules with histopathological alterations like swelling, cytoplasmic vacuolization, desquamation or necrosis was registered and the data were expressed as percentage of damaged tubules. The percentage of damaged tubules of $\mathrm{K}_{2} \mathrm{Cr}_{2} \mathrm{O}_{7}$ and control groups was compared.

\section{Immunohistochemical localization of 3-NT, protein carbonyls, Cu, Zn-SOD, Mn-SOD, and CAT}

For immunohistochemistry, $4 \mu \mathrm{m}$ sections were deparaffined with xylol and rehydrated with ethanol. Endogenous peroxidase was quenched/inhibited with $4.5 \% \mathrm{H}_{2} \mathrm{O}_{2}$ in methanol by incubation for $1.5 \mathrm{~h}$ at room temperature. The sections used for DNP immunohistochemistry were incubated with $0.2 \% \mathrm{DNPH}$ in $2 \mathrm{~N} \mathrm{HCl}$ for $60 \mathrm{~min}$ at room temperature in absence of light and then were extensively washed with phosphate buffer saline. Nonspecific adsorption was minimized by leaving the sections in $3 \%$ bovine serum albumin in phosphate buffer saline for $30 \mathrm{~min}$. Sections were incubated overnight with a 1:700 dilution of anti-3-NT antibodies [15], or a 1:500 dilution of anti-DNP antibodies, or a 1:250 dilution of anti $\mathrm{Cu}$, Zn-SOD antibodies, or a 1:500 dilution of anti Mn-SOD antibodies, or a 1:500 dilution of anti CAT antibodies. The sections were incubated with a 1:500 dilution of a peroxidase conjugated anti-rabbit immunoglobulin antibodies (for 3-NT, Cu, Zn-SOD, Mn-SOD, and CAT) or with a 1:500 dilution of a peroxidase conjugated anti-goat Ig (for DNP) for $1 \mathrm{~h}$, and finally incubated with $\mathrm{H}_{2} \mathrm{O}_{2}$ diaminobenzidine for $1 \mathrm{~min}$. Sections were counterstained with hematoxylin and observed under light microscopy. All the sections were incubated under the same conditions with the same concentration of antibodies, and in the same running, so the immunostaining was comparable among the different experimental groups. The stained area was quantified using a SigmaScan Pro (version 4.01.003) (Jandel Scientific, San Rafael, CA). The data are expressed as percent respect to day 0 .

\section{Urinary excretion of $\mathrm{NO}_{2}-/ \mathrm{NO}_{3}-$}

Nitric oxide (NO) is a labile substance with a short halflife and it decomposes rapidly to $\mathrm{NO}_{2}^{-}$and $\mathrm{NO}_{3}{ }^{-}$in biological solutions [36], and these stable breakdown products have been measured as an index of NO production [37]. $\mathrm{NO}_{2}{ }^{-}$and $\mathrm{NO}_{3}{ }^{-}$were measured in the 24-hour urine samples at all time points. Urine samples were first 


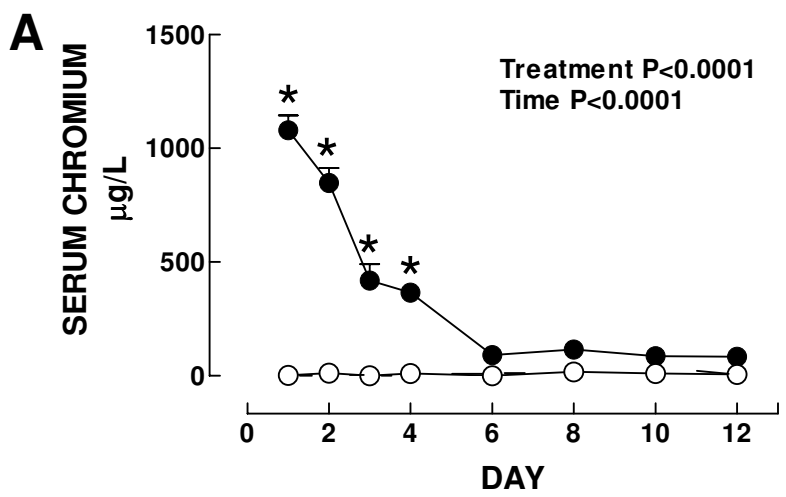

B

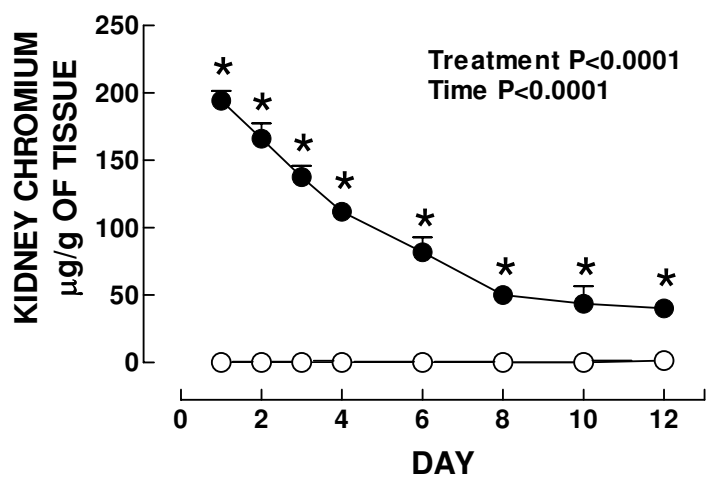

\section{Figure I}

Chromium concentration in $(A)$ serum and $(B)$ kidney in control $(O)$ and $\mathrm{K}_{2} \mathrm{Cr}_{2} \mathrm{O}_{7}(\mathbf{O})$-treated rats. Data are mean \pm SEM. ${ }^{*} P<0.00$ I vs. control group. $n=3-6$.

incubated with $E$. coli nitrate reductase to convert the $\mathrm{NO}_{3}$ to $\mathrm{NO}_{2}{ }^{-}$, as described previously $[38,39]$. To prepare this enzyme, E. coli was grown for 18 hours under anaerobic conditions in nitrate rich medium, washed, resuspended in phosphate buffer and frozen at $-70^{\circ} \mathrm{C}$ until use. The samples were incubated with the enzyme in phosphate ammonium formate buffer $(\mathrm{pH} 7.3)$ for one hour at $37^{\circ} \mathrm{C}$. After incubation, total $\mathrm{NO}_{2}$ - in the samples (representing both $\mathrm{NO}_{2}{ }^{-}$and reduced $\mathrm{NO}_{3}^{-}$) was measured using the Griess reagent. Known concentrations of $\mathrm{NaNO}_{2}$ and $\mathrm{NaNO}_{3}$ were used as standards in each assay. Data were expressed as $\mathrm{nmol} / \mathrm{min}$.

\section{Activity of antioxidant enzymes}

Kidney was homogenized in a Polytron (Model PT 2000, Brinkmann, Westbury, NY, USA) for 10 seconds in cold $50 \mathrm{mM}$ potassium phosphate, $0.1 \%$ Triton $\mathrm{X}-100, \mathrm{pH}=$ 7.0. The homogenate was centrifuged at $19,000 \times \mathrm{g}$ and $4^{\circ} \mathrm{C}$ for $30 \mathrm{~min}$ and the supernatant was separated to measure total protein and the activities of CAT, GPx, GR, and total SOD.

Total SOD activity in renal cortex homogenates was assayed spectrophotometrically at $560 \mathrm{~nm}$ by a previously reported method using NBT as the indicator reagent [34]. The amount of protein that inhibited NBT reduction to $50 \%$ of maximum was defined as one unit of SOD activity. Results were expressed as $\mathrm{U} / \mathrm{mg}$ protein. CAT activity in renal cortex, was assayed by a method based on the disappearance of $30 \mathrm{mM} \mathrm{H}_{2} \mathrm{O}_{2}$ at $240 \mathrm{~nm} \mathrm{[34]} \mathrm{and} \mathrm{the} \mathrm{data}$ were expressed as $k / \mathrm{mg}$ protein. GPx activity in renal cortex was measured at $340 \mathrm{~nm}$ using GR and NADPH in a coupled reaction [34]. One unit of GPx was defined as the amount of enzyme that oxidize $1 \mu \mathrm{mol}$ of $\mathrm{NADPH} / \mathrm{min}$. Data were expressed as $\mathrm{U} / \mathrm{mg}$ protein. GR activity in renal cortex was assayed using oxidized glutathione as substrate and measuring the disappearance of NADPH at $340 \mathrm{~nm}$ [34]. One unit of GR was defined as the amount of enzyme that oxidize $1 \mu \mathrm{mol}$ of $\mathrm{NADPH} / \mathrm{min}$. Data were expressed as $\mathrm{U} / \mathrm{mg}$ protein.

\section{Western blot}

Renal cortex (100 mg) was homogenized in $300 \mu \mathrm{l}$ of phosphate buffer $50 \mathrm{mM}$, pH 7.4 containing the following cocktail of protease inhibitors: leupeptin $5 \mu \mathrm{g} / \mathrm{ml}$, pepstatin $7 \mu \mathrm{g} / \mathrm{ml}$, aprotinin $5 \mu \mathrm{g} / \mathrm{ml}$, and EDTA $1 \mathrm{mM}$. The homogenates were centrifuged at $1,000 \times \mathrm{g}$ and $4{ }^{\circ} \mathrm{C}$ for $10 \mathrm{~min}$. Thirty $\mu \mathrm{g}$ of protein were fractionated by reducing $12.5 \%$ sodium dodecyl sulfate polyacrylamide gel electrophoresis and electroblotted to a nitrocellulose membrane (Hybond ${ }^{\mathrm{TM}}$ ECL $^{\mathrm{TM}}$, Amersham, Buckinghamshire, England). Immunodetection was performed using specific primary antibodies against CAT (1:500 dilution), Mn-SOD (1,5000 dilution), or Cu, Zn-SOD (1:5,000 dilution). Membranes were then probed with the appropriate secondary antibody-peroxidase conjugate (1:5,000 dilution). The hybrids were visualized using ECL detection system and quantified by densitometry (Sigma ScanPro, version 4.0, San Rafael, CA, USA). Data were expressed as $\%$ of the control.

\section{Statistics}

The data are expressed as the mean \pm SEM and were analyzed by two-way analysis of variance followed by Bonferroni t-test using the software Prism 2.01 (GraphPad, San Diego, CA, USA). A P value less than 0.05 was considered statistically significant.

\section{Results and discussion}

ROS have been involved in the pathophysiology of ARF induced by $\mathrm{K}_{2} \mathrm{Cr}_{2} \mathrm{O}_{7}$ and some antioxidants are able to ameliorate renal damage induced by this compound $[15,16,18,23,25]$. In addition, it has been previously 
A

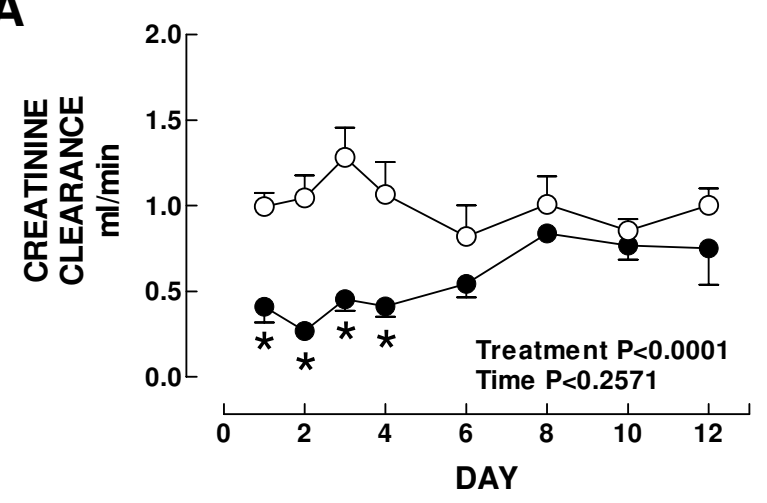

B
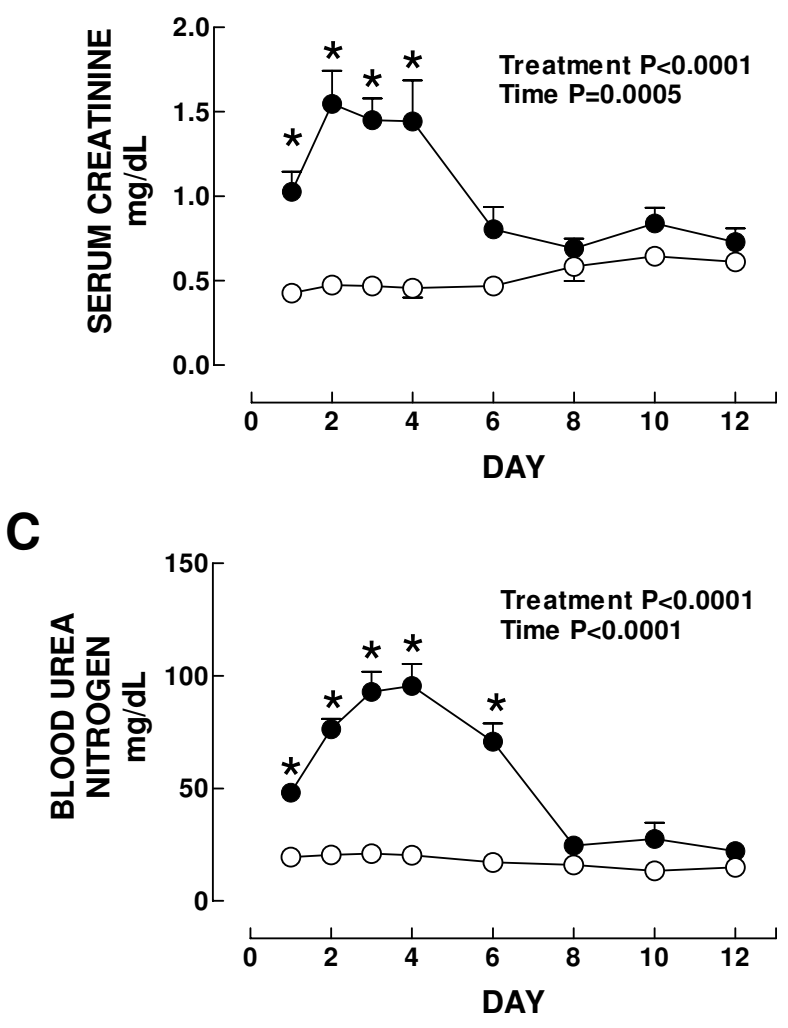

Figure 2

(A) Creatinine clearance, (B) serum creatinine, and (C) blood urea nitrogen control $(\mathrm{O})$ and $\mathrm{K}_{2} \mathrm{Cr}_{2} \mathrm{O}_{7}(\mathrm{O})$-treated rats. Data are mean \pm SEM. *P at least $<0.05$ vs. control group. $n=$ 4-6.

shown that renal heme oxygenase-1 preinduction by $\mathrm{SnCl}_{2}$ ameliorates ARF and prevents oxidative and nitrosative stress induced $24 \mathrm{~h}$ after $\mathrm{K}_{2} \mathrm{Cr}_{2} \mathrm{O}_{7}$ injection [15,34]. In the present work we performed a time-course analysis of

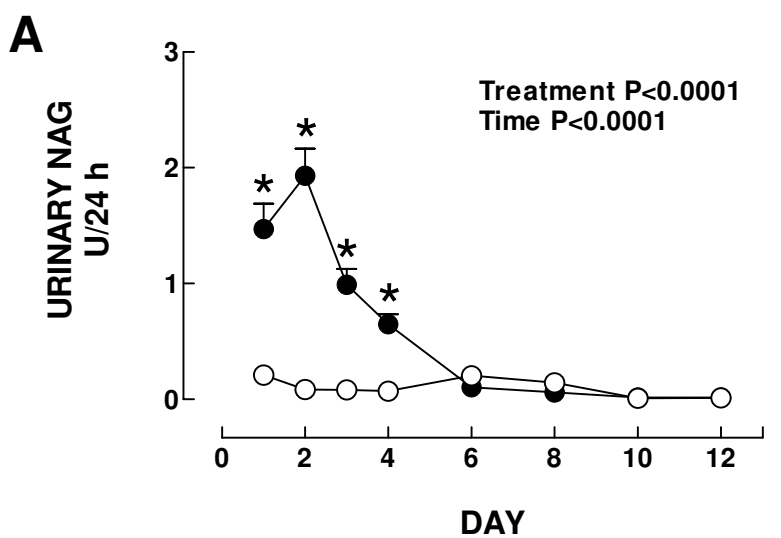

B

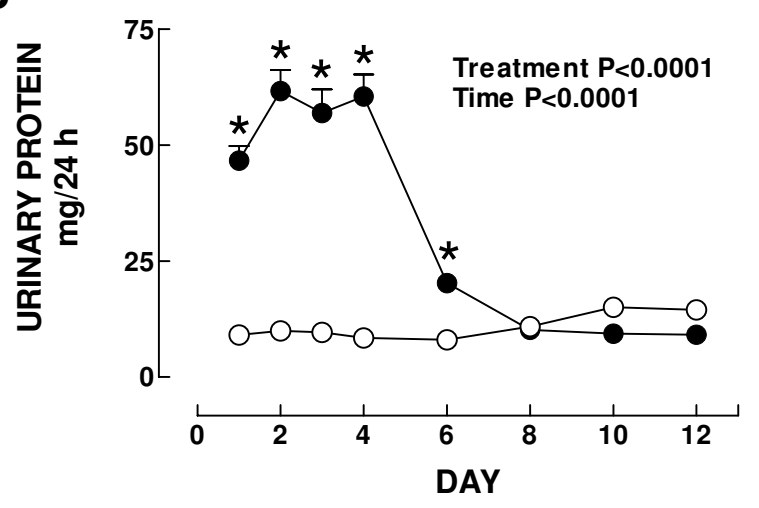

Figure 3

Urinary excretion of (A) NAG and (B) total protein in control $(\mathrm{O})$ and $\mathrm{K}_{2} \mathrm{Cr}_{2} \mathrm{O}_{7}(\mathrm{O})$-treated rats. Data are mean \pm SEM. *P at least $<0.05$ vs. control group. $n=4-18$.

the nephrotoxicity, oxidative and nitrosative stress, and changes in antioxidant enzymes induced by $\mathrm{K}_{2} \mathrm{Cr}_{2} \mathrm{O}_{7}$. Body weight of control and $\mathrm{K}_{2} \mathrm{Cr}_{2} \mathrm{O}_{7}$-treated rats was similar at all time points (see additional file 1 ). Urinary volume was increased in $\mathrm{K}_{2} \mathrm{Cr}_{2} \mathrm{O}_{7}$-treated animals on days 3 (1.9-fold) and 4 (1.6-fold) and returned to control values thereafter (see additional file 1). Polyuria observed in our rats is consistent with previous data [2]. We measured the chromium content in serum and kidney and it was found that it increased on days $1-6$ and $1-12$, respectively (Fig. 1 ). In both cases the peak value was reached on day 1 and then the chromium concentration decreased gradually, but in kidney remained still significantly high on day 12 and in serum reached values not different from control rats since day 6 . Our data are consistent with previous pharmacokinetic studies which have shown that chromium is rapidly distributed [40] and that the half life of chromium is longer in kidney than in blood serum [41]. 

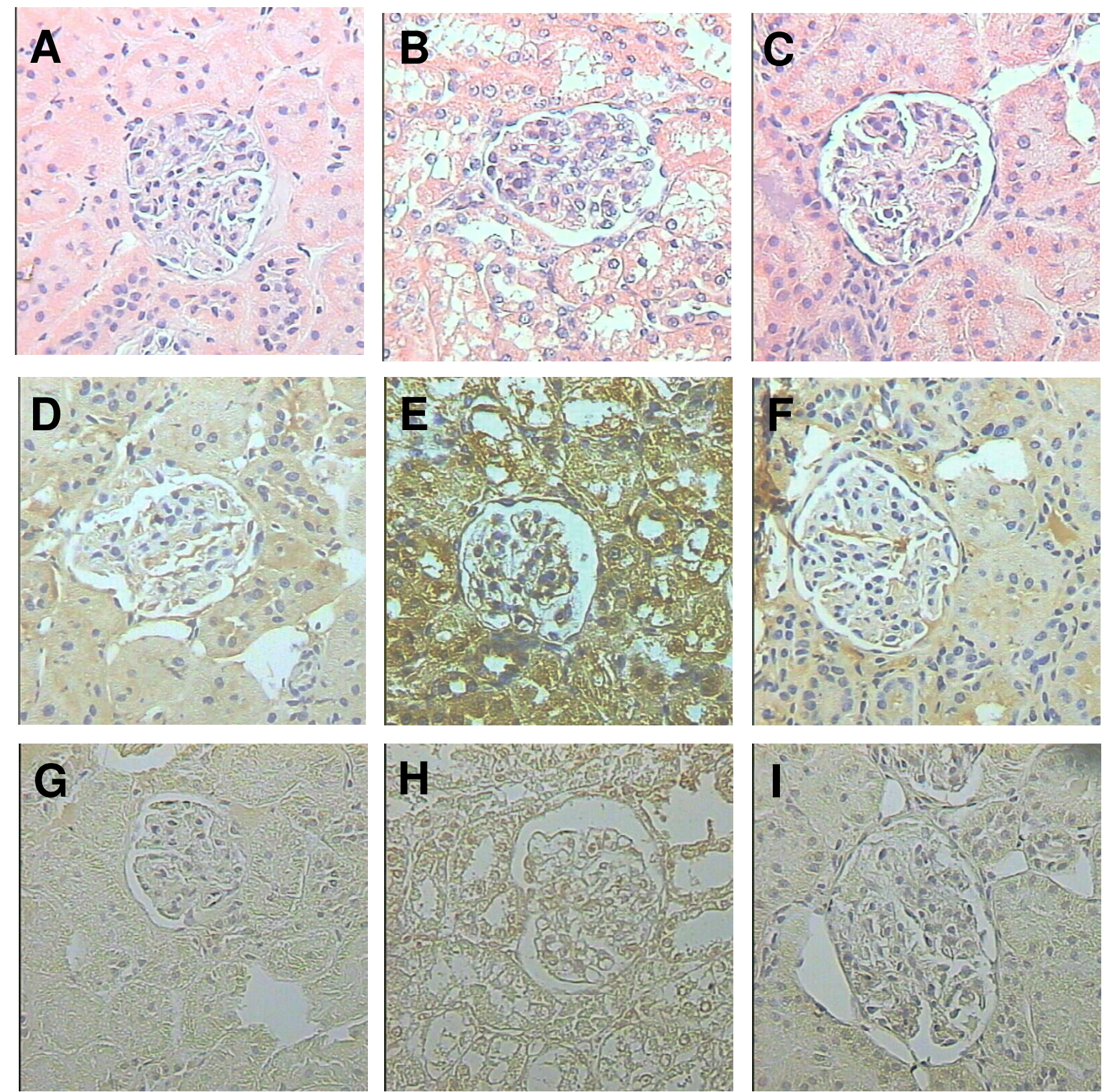

\section{Figure 4}

Representative images of histology (first row) and immunohistochemical detection of 3-NT (second row) and DNP (third row) during the evolution of the kidney damage produced by $\mathrm{K}_{2} \mathrm{Cr}_{2} \mathrm{O}_{7}$. The study was performed in control rats (day 0 ) and on days 2 and 12 after a single injection of $\mathrm{K}_{2} \mathrm{Cr}_{2} \mathrm{O}_{7}(\mathrm{I} 5 \mathrm{mg} / \mathrm{Kg})$. (A) Normal kidney histology from control rat $(\mathrm{H} / \mathrm{E})$. (B) On day 2, there is extensive tubular damage manifested by swollen and necrotic epithelial cells $(H / E)$. (C) total kidney regeneration has been produced on day $\mathrm{I} 2$ post $\mathrm{K}_{2} \mathrm{Cr}_{2} \mathrm{O}_{7}$ administration (H/E). (D) Normal kidney from control animals shows scarce 3-NT immunoreactivity. (E) On day 2, there is strong 3-NT immunostaining in the epithelium from the convoluted tubules. (F) Slight 3-NT immunostaining is observed in the tubular epithelium on day I2. (G) Normal kidney from control rat shows scarce DNP immunostaining in the tubular epithelium. $(\mathrm{H})$ In contrast, on day 2 there is clear DNP immunostaining in the cytoplasm and nucleus of the tubular epithelial cells and mesangium. (I) Slight DNP immunostaining is observed on day 12 . $400 \mathrm{X}$. 
Table I: Quantitative analysis of 3-NT, DNP, catalase, Cu, Zn-SOD, and Mn-SOD immunostaining.

\begin{tabular}{llll}
\hline & Day 0 & Day 2 & Day I2 \\
\hline 3-Nitrotyrosine & $100 \pm 11(4)$ & $392 \pm 33(4)^{*}$ & $113 \pm 13(4)$ \\
Dinitrophenol & $100 \pm 11(4)$ & $172.03 \pm 9 *(4)$ & $106.81 \pm 9(4)$ \\
Catalase & $100 \pm 6(5)$ & $82 \pm 6.7(4)$ & $107 \pm 4.9(4)$ \\
Cu, Zn-SOD & $100 \pm 3(4)$ & $90 \pm 8(4)$ & $91 \pm 7(4)$ \\
Mn-SOD & $100 \pm 5(3)$ & $94 \pm 6(3)$ & $110 \pm 5(3)$ \\
\hline
\end{tabular}

Data are expressed as percentage vs. day $0 . * \mathrm{P}<0.001$ vs. day 0 .

Number of rats studied are in parentheses.

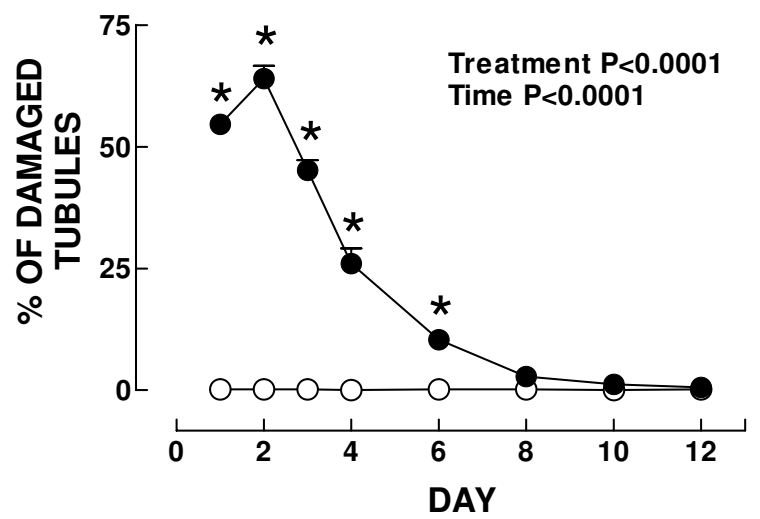

Figure 5

Quantitative histological analysis in control $(\mathrm{O})$ and $\mathrm{K}_{2} \mathrm{Cr}_{2} \mathrm{O}_{7}$ (-) -treated rats. Data are mean \pm SEM. ${ }^{*} \mathrm{P}<0.05$ vs. control group. $n=20$ tubules/rat and 5 rats/group.

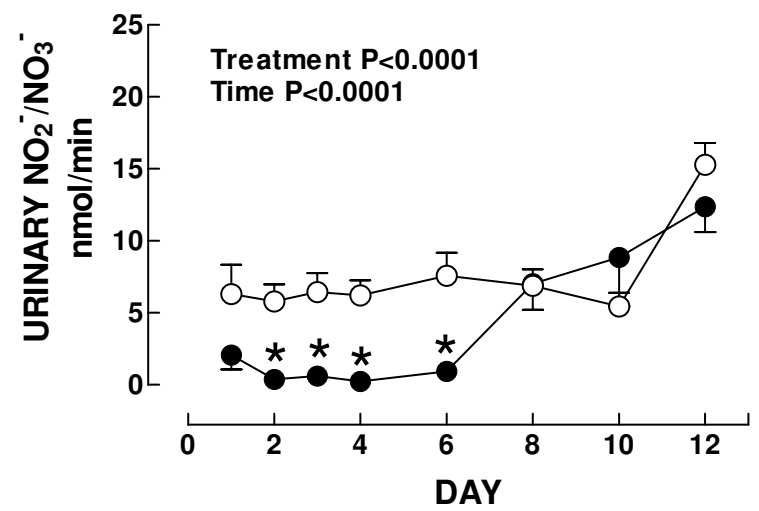

Figure 6

Urinary excretion of $\mathrm{NO}_{2}{ }^{-} / \mathrm{NO}_{3}{ }^{-}$in control $(O)$ and $\mathrm{K}_{2} \mathrm{Cr}_{2} \mathrm{O}_{7}$ (๑)-treated rats. Data are mean \pm SEM. *P $<0.05$ vs. Control group. $n=4-10$.
Markers of nephrotoxicity are shown in Figs. 2 and 3. Creatinine clearance decreased on days 1-4 (Fig. 2A), and serum creatinine and BUN increased on days 1-4 and 16 , respectively (Figs. 2B and 2C). Urinary excretion of NAG and total protein increased on days 1-4 and 1-6, respectively (Figs. $3 \mathrm{~A}$ and $3 \mathrm{~B}$ ). The major damage was observed on days 2-4 (Figs. 2 and 3). On day 8, all these markers returned to control values indicating that $\mathrm{K}_{2} \mathrm{Cr}_{2} \mathrm{O}_{7}$-induced ARF is reversible which is consistent with previous observations [10]. These functional findings are in a close agreement with the histological data. Significant structural abnormalities were seen in the kidney cortex since the first day after $\mathrm{K}_{2} \mathrm{Cr}_{2} \mathrm{O}_{7}$ administration. Specifically, $50 \%$ of the epithelium from the proximal convoluted tubules showed cellular swelling, necrosis and partial or complete detachment from the basal membrane. On day 2, when the peak of the tubular damage was observed, $70 \%$ of the proximal convoluted tubules was affected (Figs. 4B and 5). On days 3 and 4 proximal convoluted tubules showing the above mentioned abnormalities decreased to 40 and 25\%, respectively (Fig. 5). On day 4, many tubules also showed numerous cellular debris in their lumen and epithelium regeneration was also seen but it was more evident on days 6 and 8 (data not shown). On days 10 and 12 the kidney histology was almost normal (Fig. 4C), only few tubules were revisted by active regenerative epithelium (small cuboidal cells with big nucleus and occasional mitotic figures). The high levels of serum and kidney chromium correlated with the structural and functional renal alterations on days 1-6. Interestingly, the renal damage disappeared in spite of the kidney still having high levels of chromium on days 8-12. This may be explained by the fact that chromium (VI), which is readily taken up into tissues, is reduced inside the cell to the final stable product chromium (III) [19]. The biological effects of chromium (VI) are generally attributed to cellular uptake, because chromium (VI), in contrast to chromium (III), is easily taken up by cells through the sulfate anion transport system $[42,43]$. However, once inside, chromium (VI) is reduced through reactive intermediates such as chromium (V) and chromium (IV) to the more stable chromium (III) by cellular reductants includ- 

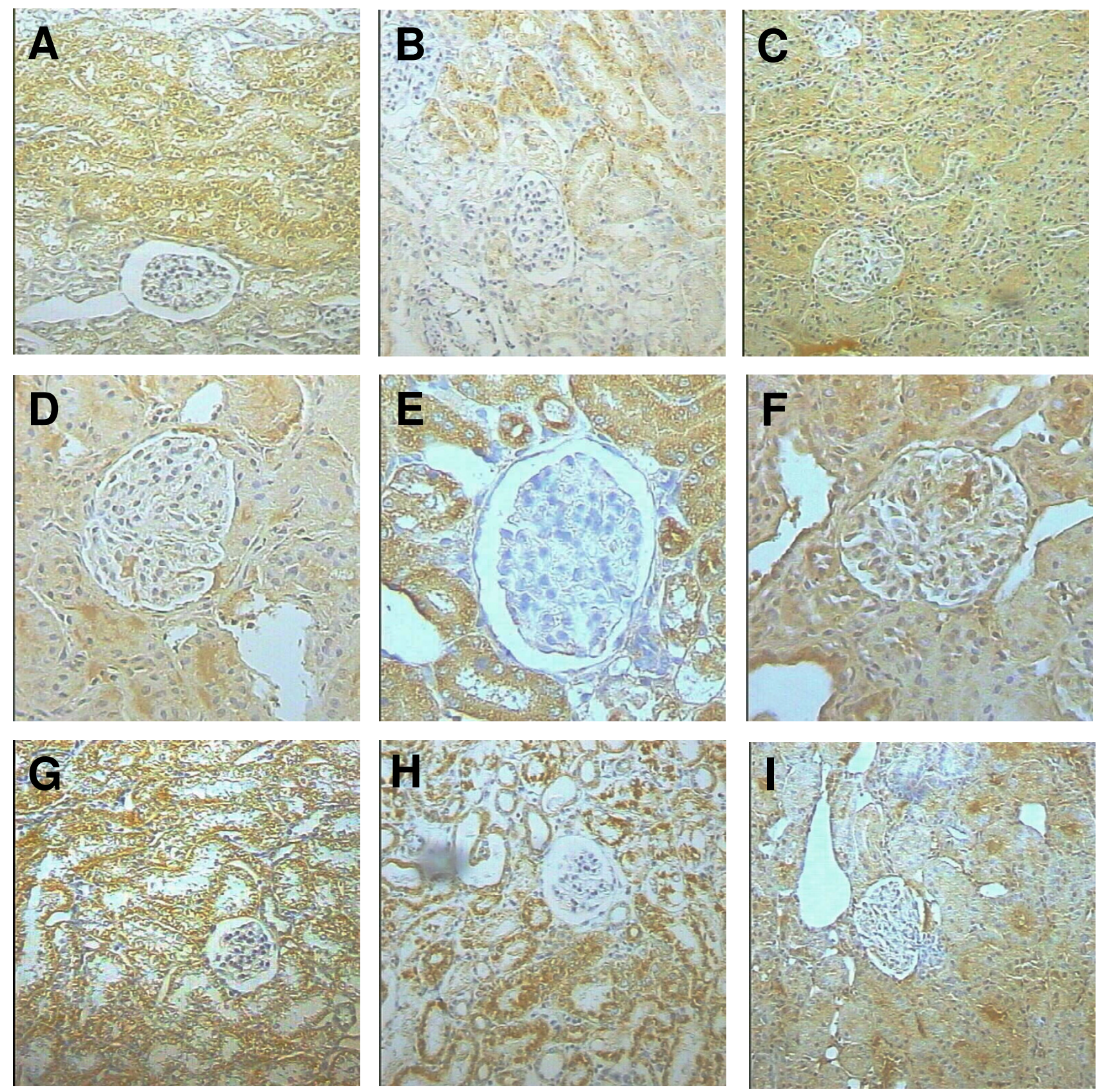

\section{Figure 7}

Representative immunohistochemical detection of CAT (first row), Cu, Zn-SOD (second row), and Mn-SOD (third row) during acute renal failure induced by $\mathrm{K}_{2} \mathrm{Cr}_{2} \mathrm{O}_{7}$. The study was performed in control rats (day 0 ) and on days 2 and $\mathrm{I} 2$ after a single injection of $\mathrm{K}_{2} \mathrm{Cr}_{2} \mathrm{O}_{7}(15 \mathrm{mg} / \mathrm{Kg})$. (A) Normal kidney from control rats shows intense CAT immunoreactivity in the proximal and distal convoluted tubules. (B) In contrast, kidney cortex on day 2 shows evident decrease of CAT immunostaining. (C) Strong CAT immunoreactivity in the tubular epithelium is observed on day I2. (D) Normal kidney from control animals also showed strong $\mathrm{Cu}, \mathrm{Zn}-\mathrm{SOD}$ immunostaining in the cortex convoluted tubules. This strong $\mathrm{Cu}, \mathrm{Zn}$-SOD immunoreactivity is also observed on day 2 (E) and on day I2 (F). A similar pattern of Mn-SOD immunostaining is observed in normal kidney from control rat $(\mathrm{G})$, and after $2(\mathrm{H})$ and $\mathrm{I} 2(\mathrm{I})$ days of $\mathrm{K}_{2} \mathrm{Cr}_{2} \mathrm{O}_{7}$ injection. A-C and G-I I00X, D-F 400X. 
ing glutathione, vitamins $\mathrm{C}$ and $\mathrm{B}_{2}$, and flavoenzymes [42]. Thus, the formation of chromium (III) or other intermediate oxidation states, in particular chromium $(\mathrm{V})$, is believed to play a role in the biological effect of chromium (VI) compounds. In vitro studies have shown that this reduction process causes the generation of active oxygen species [44] which are involved in renal damage $[15,34]$. Interestingly, it has been shown that a low dose of $\mathrm{K}_{2} \mathrm{Cr}_{2} \mathrm{O}_{7}(10 \mathrm{mg} / \mathrm{Kg})$ is unable to induce nephrotoxicity suggesting a threshold of this compound to induce renal damage [10]. In addition, it is know that chromium is located in vacuoles inside the proximal tubular cells which may delay the excretion of this metal [13]. In fact it has been shown that chromium remains for a long time in several tissues including kidney $[13,40,41]$ which is consistent with our data.

The histological abnormalities correlated with renal functional alterations (days 1-6) and with the immunohistochemical detection of 3-NT and protein carbonyls. DNPH reacts with free carbonyls forming DNP-derived proteins which can be detected using antibodies against DNP. Carbonyl derivatives are formed by ROS mediated oxidation of side-chains of some amino acid residues and are important detectable markers of oxidative damage to proteins [45]. Kidneys from control non-treated animals did not show or only had slight immunostaining to 3-NT or protein carbonyls (Figs. 4D and 4G), while kidneys from $\mathrm{K}_{2} \mathrm{Cr}_{2} \mathrm{O}_{7}$-treated animals on day 2 showed strong 3-NT immunostaining in necrotic and swollen tubular epithelial cells, as well as some mesangial cells (Fig. 4E). This increase was significative $(\mathrm{P}<0.0001$ vs. day 0$)$ (Table 1$)$. In fact, it was observed from day 1 to day 8 (data not shown). Protein carbonyls immunostaining was also clear in the cytoplasm and nuclei from tubular epithelium and mesangial glomerular cells at the same time points (Fig. $4 \mathrm{H}$ and data not shown) ( $\mathrm{P}<0.001$ vs. day 0$)$ (Table 1$)$. Then, on days 10 to 12 , a striking decrease of 3-NT and DNP immunostaining was seen, being similar to the control non-treated rats (Figs. $4 \mathrm{~F}$ and $4 \mathrm{I}$ ). In previous works, we also have found in $\mathrm{K}_{2} \mathrm{Cr}_{2} \mathrm{O}_{7}$-treated rats an intense 3-NT immunostaining [15] and an increase in protein carbonyl content $[15,34]$. Our data confirm that ROS are involved in $\mathrm{K}_{2} \mathrm{Cr}_{2} \mathrm{O}_{7}$-induced nephrotoxicity $[16,17,19,26,44]$ which has additionally been supported by the protective effect of several antioxidants in this experimental model [21-25].

On the other hand, it was found that urinary excretion of $\mathrm{NO}_{2}-\mathrm{NO}_{3}$ - decreased significantly in $\mathrm{K}_{2} \mathrm{Cr}_{2} \mathrm{O}_{7}$-treated rats on days 2-6 (Fig. 6). Urinary excretion of $\mathrm{NO}_{2}-/ \mathrm{NO}_{3}{ }^{-}$is considered as an index of NO production [37] and therefore these data may suggest that NO production is decreased in $\mathrm{K}_{2} \mathrm{Cr}_{2} \mathrm{O}_{7}$-treated rats. However, the strong nitrosative stress observed in our rats by 3 -NT immunos-
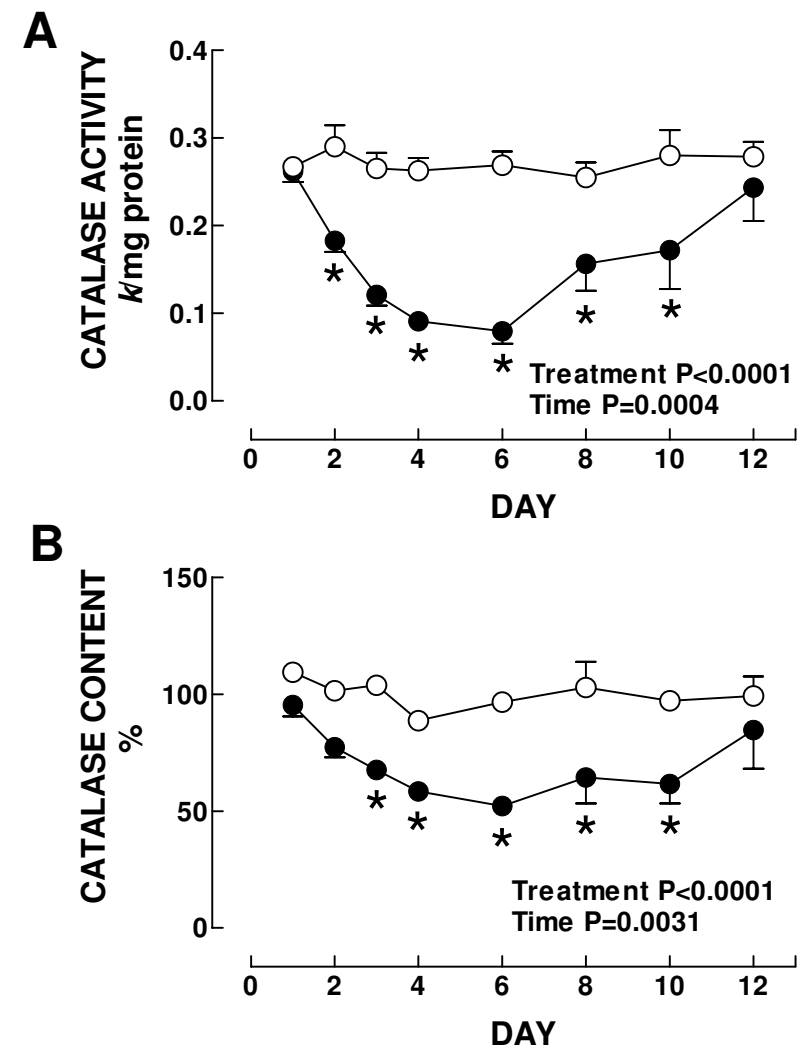

Figure 8

(A) Activity and (B) content of CAT in kidney from control (O) and $\mathrm{K}_{2} \mathrm{Cr}_{2} \mathrm{O}_{7}(\mathrm{O})$-treated rats. Data are mean \pm SEM. *P at least $<0.05$ vs. control group. $n=4-6$.

taining, may suggest that the decrease in urinary $\mathrm{NO}_{2}-\%$ $\mathrm{NO}_{3}^{-}$excretion could be secondary to the $\mathrm{NO}$ consumption by its reaction with superoxide anion to generate peroxynitrite and other reactive nitrogen species involved in protein tyrosine nitration [46]. This is supported by the association between the time course alterations in 3-NT immunostaining (days 1-8) and the decrease in urinary $\mathrm{NO}_{2}-/ \mathrm{NO}_{3}{ }^{-}$excretion (days 2-6).

Further we investigated the time response of the renal antioxidant enzymes in $\mathrm{K}_{2} \mathrm{Cr}_{2} \mathrm{O}_{7}$-treated rats. In control rats, strong CAT immunostaining was seen in the epithelial cells from proximal and distal convoluted tubules (Fig. 7A). From day 2 to day 10 after $\mathrm{K}_{2} \mathrm{Cr}_{2} \mathrm{O}_{7}$ administration, CAT immunostaining showed striking decrease, particularly in the epithelium from tubules with evident cellular damage (Fig. 7B and data not shown). Then, at 


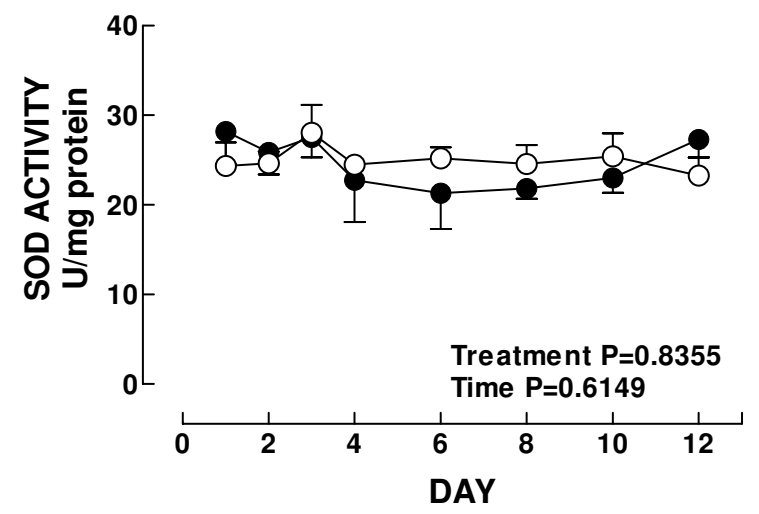

Figure 9

Total superoxide dismutase activity in kidney from control (O) and $\mathrm{K}_{2} \mathrm{Cr}_{2} \mathrm{O}_{7}(\mathrm{O}$ )-treated rats. Data are mean \pm SEM. $n=$ 3-6.

day 12, when almost normal kidney histology was seen, strong CAT immunostaining was observed in a similar pattern than in the kidney from control animals (Fig. 7C). CAT activity (Fig. 8A) and content (Fig. 8B) decreased on days $2-10$ and $3-10$, respectively. In control animals the epithelial cells from the proximal and convoluted tubules showed strong immunoreactivity to $\mathrm{Cu}, \mathrm{Zn}-\mathrm{SOD}$ and $\mathrm{Mn}$ SOD (Figs. 7D and 7G). This pattern of immunostaining did not show evident changes during the time course study (days 1-12) (Figs. 7E, 7F, 7H, 7I, and data not shown); even the damaged swollen epithelial tubular cells exhibited strong immunostaining to both SOD enzymes. These data are in agreement with kidney total SOD activity (Fig. 9) and with the protein content of Mn-SOD and $\mathrm{Cu}, \mathrm{Zn}$-SOD measured by Western blot which remained unchanged at all time points in $\mathrm{K}_{2} \mathrm{Cr}_{2} \mathrm{O}_{7}$-treated rats (data not shown). Finally, the activity of GPx and GR decreased on days 3-12 and on days 2-10, respectively (Fig. 10). It is very clear from the above data that there was a differential response of the antioxidant enzymes to $\mathrm{K}_{2} \mathrm{Cr}_{2} \mathrm{O}_{7}$ injection. Interestingly, no enzyme (SOD, CAT, GPx, and GR) was altered on day 1 when the kidney damage was very severe. Surprisingly, SOD activity and content remained essentially unchanged at all time points. This may be a consequence of the fact that both SOD enzymes were immunolocalized even in the damaged epithelial tubular cells. In contrast, the other enzymes decreased to reach their lowest values on day 6 returning then to basal values by day 12 with the exception of GPx which remained low. On days 2-6, there was some degree correlation between CAT, GPx, and GR and the markers of nephrotoxicity. However, from day 8 these enzymes remained low in spite

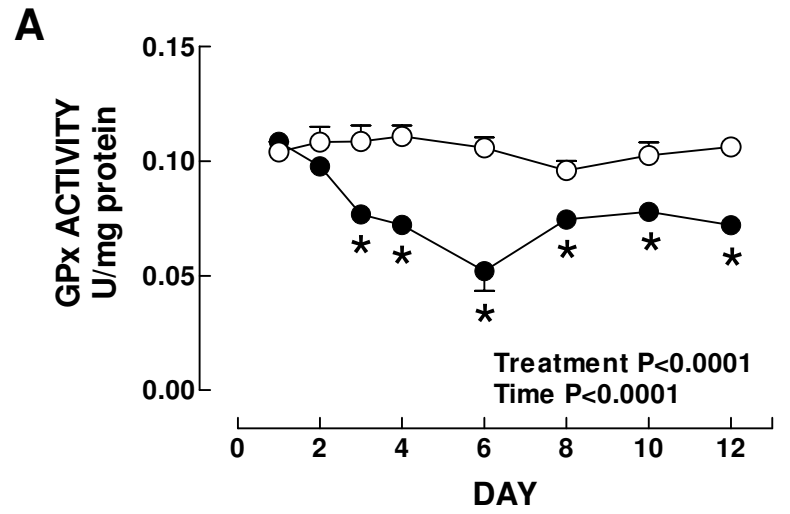

B

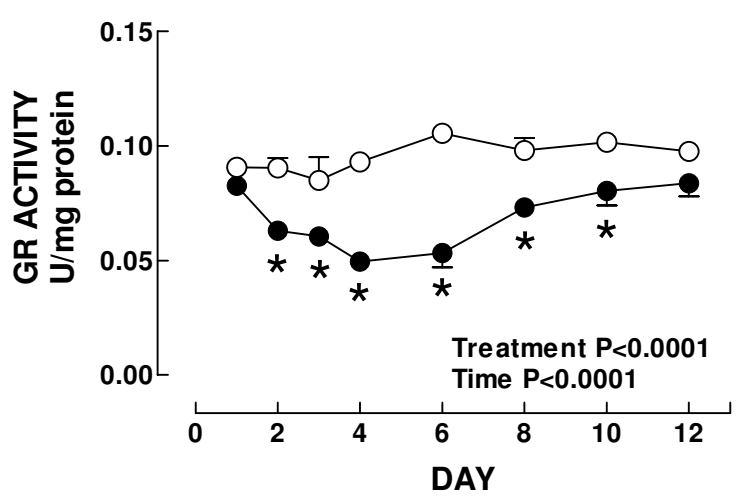

Figure 10

Activity of $(A)$ glutathione peroxidase and $(B)$ glutathione reductase in kidney from control $(\bigcirc)$ and $\mathrm{K}_{2} \mathrm{Cr}_{2} \mathrm{O}_{7}(-)$ treated rats. Data are mean \pm SEM. *P at least $<0.05$ vs. control group. $n=5-6$.

of renal function and structure returned to control. Furthermore, the time course study suggests that the decrease in GPx, GR, and CAT activities may be secondary to the oxidative and nitrosative stress which are evident since day 1 . In fact, it has been demonstrated that peroxynitrite impairs GPx activity [47] and superoxide anion inactivates GPx [48] and CAT [49]. Interestingly, GR and CAT remained low until day 10 and GPx remained low until day 12 in absence of oxidative and nitrosative stress. The reason why these enzymes remained low at the end of the study is not clear, however we may speculate that factors other than oxidative/nitrosative stress are involved in the diminution in these enzymes and/or proximal tubules have not reached yet the full capacity to synthesize these enzymes. Therefore, additional studies are required to explain why some antioxidant enzymes remained low on days 10-12 in absence of oxidative/nitrosative stress. 


\section{Conclusion}

The data show an association between oxidative/nitrosative stress and functional and structural renal damage induced by $\mathrm{K}_{2} \mathrm{Cr}_{2} \mathrm{O}_{7}$ in rats at different time points, but not between this damage and antioxidant enzymes.

\section{List of abbreviations used}

ARF Acute renal failure

BUN Blood urea nitrogen

CAT Catalase

$\mathrm{Cu}, \mathrm{Zn}$-SOD Copper and zinc superoxide dismutase

DNP Dinitrophenol

DNPH 2,4-dinitrophenylhydrazine

ECL Enhanced chemiluminiscence

GPx Glutathione peroxidase

GR Glutathione reductase

$\mathrm{H}_{2} \mathrm{O}_{2}$ Hydrogen peroxide

$\mathrm{K}_{2} \mathrm{Cr}_{2} \mathrm{O}_{7}$ Potassium dichromate

Mn-SOD Manganese superoxide dismutase

NADPH Nicotinamide adenine dinucleotide phosphate

NAG N-acetyl- $\beta$-D-glucosaminidase

NBT Nitroblue tetrazolium

NO Nitric oxide

$\mathrm{NO}_{2}$ - Nitrate

$\mathrm{NO}_{3}{ }^{-}$Nitrite

3-NT 3-Nitrotyrosine

ROS Reactive oxygen species

SEM Standard error of the mean

\section{Competing interests}

The author(s) declare that they have no competing interests.

\section{Authors' contributions}

JPCH conceived and coordinated the study and wrote and edited the manuscript. DB performed histological, immunohistochemical and statistical analyses. Coordinated the study and wrote the manuscript. ONMC performed Western blot analysis. RCC performed animal studies and collected samples. RHP performed the histological and immunohistochemical analyses. NAMR performed animal studies and collected samples. PDM measured antioxidant enzyme activity. MIS performed animal studies and collected samples. ET measured urinary excretion of $\mathrm{NO}_{2}-\mathrm{NO}_{3}{ }^{-}$. LS and MEC measured chromium concentration. MEIR coordinated the study and edited the manuscript.

\section{Additional material}

\section{Additional File 1}

(A) Body weight, and (B) urinary volume in control (O) and $\mathrm{K}_{2} \mathrm{Cr}_{2} \mathrm{O}_{7}$ (O)-treated rats. Data are mean \pm SEM. ${ }^{*}$ P at least $<0.01$ vs. control group. $\mathrm{n}=5-18$.

Click here for file

[http://www.biomedcentral.com/content/supplementary/14712369-6-4-S1.doc]

\section{Acknowledgements}

This work was supported by CONACYT (\#2544I) given to MEIR and DGAPA (IN2I 020I) given to JPCH.

\section{References}

I. Barceloux DG: Chromium. J Toxicol Clin Toxicol 1999, 37:173-194.

2. Verschoor MA, Braget PC, Herber RFM, Zielhuis RL, Zwennis WC: Renal function of chrome-plating workers and welders. Int Arch Occup Environ Health 1988, 60:67-70.

3. Ingber A, Gammelgaard B, David M: Detergents and bleaches are sources of chromium contact dermatitis in Israel. Contact Dermatitis 1998, 38:101-104.

4. Norseth $\mathrm{T}$ : The carcinogenicity of chromium and its salts. $\mathrm{Br}$ J Ind Med 1986, 43:649-65I.

5. Sharma BK, Singhal PC, Chugh KS: Intravascular haemolysis and renal failure following potassium dichromate poisoing. Postgrad Med J 1978, 54:4|4-4I5.

6. Picaud JC, Cochat P, Parchoux B, Berthier JC, Gilly J, Chareyre S, Larbre $F$ : Acute renal failure in a child after chewing of match heads. Nephron 1991, 57:225-226.

7. Pedraza-Chaverri J, Moreno-Muñiz SI, Cruz C, Hernandez-Pando R, Larriva-Sahd J, Tapia E: Urinary Angiotensin I-converting enzyme activity is increased in experimental acute renal failure. Clin Invest Med 1995, 18:424-434.

8. Michael UF, Logan JL, Meeks LA: The beneficial effects of thyroxine on nephrotoxic acute renal failure in the rat. J Am Soc Nephrol 1991, 1:1236-1240.

9. Seiken G, Grillo FG, Schaudies RP, Johnson JP: Modulation of renal EGF in dichromate-induced acute renal failure treated with thyroid hormone. Kidney Int 1994, 45:1622-1627.

10. Gumbleton M, Nicholls PJ: Dose-response and time-response biochemical and histological study of potassium dichromateinduced nephrotoxicity in the rat. Food Chem Toxicol 1988, 26:37-44.

II. Ngaha EO: Renal effects of potassium dichromate in the rat: comparison of urinary enzyme excretion with corresponding tissue patterns. Gen Pharmacol I98I, I 2:497-500. 
12. Evan AP, Dail WG: The effects of sodium chromate on the proximal tubules of the rat kidney. Fine structural damage and lysozymuria. Lab Invest 1974, 30:704-7I 5.

13. Berry JP, Hourdry J, Galle P, Lagrue G: Chromium concentration by proximal renal tubule cells: an ultrastructural, microanalytical and cytochemical study. J Histochem Cytochem 1978, 26:65I-657.

14. Franchini I, Mutti A, Cavatorta A, Corradi A, Cosi A, Olivetti G, Borghetti A: Nephrotoxicity of chromium. Remarks on an experimental and epidemiological investigation. Contrib Nephrol 1978, 10:98-I I0.

15. Barrera D, Maldonado PD, Medina-Campos ON, Hernández-Pando $\mathrm{R}$, Ibarra-Rubio ME, Pedraza-Chaverri J: HO-I induction attenuates renal damage and oxidative stress induced by $\mathrm{K}_{2} \mathrm{Cr}_{2} \mathrm{O}_{7}$. Free Radic Biol Med 2003, 34: I 390-I398.

16. Sengupta T, Chattopadhyay D, Ghosh N, Maulik G, Chatterjee GC: Impact of chromium on lipoperoxidative processes and subsequent operation of the glutathione cycle in rat rena system. Indian J Biochem Biophys I992, 29:287-290.

17. Stohs SJ, Bagchi D: Oxidative mechanisms in the toxicity of metal ions. Free Radic Biol Med 1995, I 8:321-336.

18. Huang YL, Chen CY, Sheu JY, Chuang IC, Pan JH, Lin TH: Lipid peroxidation in workers exposed to hexavalent chromium. / Toxicol Environ Health A 1999, 56:235-247.

19. Liu KJ, Shi X: In vivo reduction of chromium (VI) and its related free radical generation. Mol Cell Biochem 200I, 222:4I-47.

20. Bagchi D, Hassoun EA, Bagchi M, Stohs SJ: Chromium-induced excretion of urinary lipid metabolites, DNA damage, nitric oxide production, and generation of reactive oxygen species in Sprague-Dawley rats. Comp Biochem Physiol C Pharmacol Toxicol Endocrinol 1995, I I 0: I77-187.

21. Hojo Y, Satomi $Y$ : In vitro nephrotoxicity induced in mice by chromium (VI): involvement of glutathione and chromium (V). Biol Trace Elem Res 1991, 3 I:21-31.

22. Standeven AM, Wetterhahn KE: Possible role of glutathione in chromium(VI) metabolism and toxicity in rats. Pharmacol Toxicol 199I, 68:469-476.

23. $\mathrm{Na} \mathrm{KJ}$, Jeong SY, Lim CH: The role of glutathione in the acute nephrotoxicity of sodium dichromate. Arch Toxicol 1992 66:646-65I

24. Sugiyama $M$ : Role of physiological antioxidants in chromium(VI)-induced cellular injury. Free Radic Biol Med 1992 , I 2:397-407.

25. Appenroth D, Winnefeld $\mathrm{K}$ : Vitamin $\mathbf{E}$ and $\mathbf{C}$ in the prevention of metal nephrotoxicity in developing rats. Exp Toxicol Pathol 1998, 50:391-396.

26. Bagchi D, Stohs SJ, Downs BW, Bagchi M, Preuss HG: Cytotoxicity and oxidative mechanisms of different forms of chromium. Toxicology 2002, 180:5-22

27. O'Brien $\mathrm{P}$, Kortenkamp $\mathrm{A}$ : Chemical models important in understanding the way in which chromate can damage DNA. Environ Health Perspect 1994, I 02(Suppl 3):3-10.

28. Shi X, Dalal NS: Generation of hydroxyl radical by chromate in biologically relevant systems: role of $\mathrm{Cr}(\mathrm{VI})$ complex versus tetraperochromate(V). Environ Health Perspect 1994, I02(Supp 3):23i-236.

29. Stohs SJ: The role of free radicals in toxicity and disease. J Basic Clin Physiol Pharmacol 1995, 6:205-228.

30. Shi XL, Dalal NS: Evidence for a Fenton type mechanism for the generation of $\mathrm{OH}$ radicals in the reduction of $\mathrm{Cr}(\mathrm{VI})$ in cellular media. Arch Biochem Biophys 1990, 281:90-95.

31. Aiyar J, Berkovits HJ, Floyd RA, Wetterhahn KE: Reaction of chromium (VI) with glutathione or with hydrogen peroxide: identification of reactive intermediates and their role in chromium (VI)-induced DNA damage. Environ Health Perspect 1991, 92:53-62

32. Tsou TC, Chen CL, Liu TY, Yang JL: Induction of 8-hydroxydeoxyguanosine in DNA by chromium (III) plus hydrogen peroxide and its prevention by scavengers. Carcinogenesis 1996 17:103-108

33. Liu KJ, Shi X, Dalal NS: Synthesis of $\mathbf{C r}$ (VI)-GSH, its identification and its free hydroxyl radical generation: a model compound for $\mathrm{Cr}(\mathrm{VI})$ carcinogenicity. Biochem Biophys Res Commun 1997, 235:54-58.
34. Barrera D, Maldonado PD, Medina-Campos ON, Hernández-Pando $\mathrm{R}$, Ibarra-Rubio ME, Pedraza-Chaverri J: Protective effect of $\mathrm{SnCl}_{2}$ on $\mathrm{K}_{2} \mathrm{Cr}_{2} \mathrm{O}_{7}$-induced nephrotoxicity in rats: the indispensability of HO-I preinduction and lack of association with some antioxidant enzymes. Life Sci 2003, 73:3027-304I.

35. Toda N, Takahashi T, Mizobuchi Z, Fujii H, Nakahira K, Takahashi S, Yamashita M, Morita K, Hirakawa M: Tin chloride pretreatment prevents renal injury in rats with ischemic acute renal failure. Crit Care Med 2002, 30:1512-1522.

36. Marletta MA, Yoon PS, lyengar R, Leaf CD, Wishnok JS: Macrophage oxidation of L-arginine to nitrite and nitrate: nitric oxide is an intermediate. Biochemistry |988, 27:8706-87| I

37. Moncada S, Palmer RM, Higgs EA: Nitric oxide: physiology, pathophysiology, and pharmacology. Pharmacol Rev 1991, 43:109-142.

38. Bartholomew $B$ : A rapid method for the assay of nitrate in urine using the nitrate reductase enzyme of Escherichia coli. Food Chem Toxicol 1984, 22:54l-543.

39. Granger DL, Hibbs JB Jr, Perfect JR, Durack DT: Metabolic fate of L-arginine in relation to microbiostatic capability of murine macrophages. J Clin Invest 1990, 85:264-273.

40. O'Flaherty EJ: A physiologically based model of chromium kinetics in the rat. Toxicol Appl Pharmacol 1996, I38:54-64.

4I. Weber $\mathrm{H}$ : Long-term study of the distribution of soluble chromate-5 I in the rat after a single intratracheal administration. J Toxicol Environ Health 1983, I I:749-764.

42. De Flora S, Wetterhahn KE: Mechanism of chromium (VI) metabolism and genotoxicity. Life Chem Rep 1989, 7:169-244.

43. Dartsch PC, Hildenbrand S, Kimmel R, Schmahl FW: Investigations on the nephrotoxicity and hepatotoxicity of trivalent and hexavalent chromium compounds. Int Arch Occup Environ Health 1998, 7 I (Suppl):S40-S45.

44. Sugiyama $M$ : Role of cellular antioxidants in metal-induced damage. Cell Biol Toxicol 1994, 10:1-22.

45. Smith MA, Sayre LM, Anderson VE, Harris PL, Beal MF, Kowall N Perry G: Cytochemical demonstration of oxidative damage in Alzheimer disease by immunochemical enhancement of the carbonyl reaction with 2,4-dinitrophenylhydrazine. J Histochem Cytochem 1998, 46:731-735.

46. Radi R: Nitric oxide, oxidants, and protein tyrosine nitration. Proc Natl Acad Sci U S A 2004, I 0 I:4003-4008.

47. Padmaja S, Squadrito GL, Pryor WA: Inactivation of glutathione peroxidase by peroxynitrite. Arch Biochem Biophys 1998, 349: I-6.

48. Blum J, Fridovich I: Inactivation of glutathione peroxidase by superoxide radical. Arch Biochem Biophys 1985, 240:500-508.

49. Rister $M$, Baehner RL: The alteration of superoxide dismutase, catalase, glutathione peroxidase, and NAD(P)H cytochrome c reductase in guinea pig polymorphonuclear leukocytes and alveolar macrophages during hyperoxia. J Clin Invest 1976 , 58: I |74- | | 84.

\section{Pre-publication history}

The pre-publication history for this paper can be accessed here:

\section{http://www.biomedcentral.com/1471-2369/6/4/prepub}

Publish with Bio Med Central and every scientist can read your work free of charge

"BioMed Central will be the most significant development for disseminating the results of biomedical research in our lifetime. "

Sir Paul Nurse, Cancer Research UK

Your research papers will be:

- available free of charge to the entire biomedical community

- peer reviewed and published immediately upon acceptance

- cited in PubMed and archived on PubMed Centra

- yours - you keep the copyright 